\title{
Advanced training and international educational exchange: learning, overcoming and experiences
}

\author{
Formação avançada e intercâmbio educacional internacional: aprendizados, superações e vivências \\ Formación avanzada e intercambio educativo internacional: aprendizajes, superaciones y experiencias
}

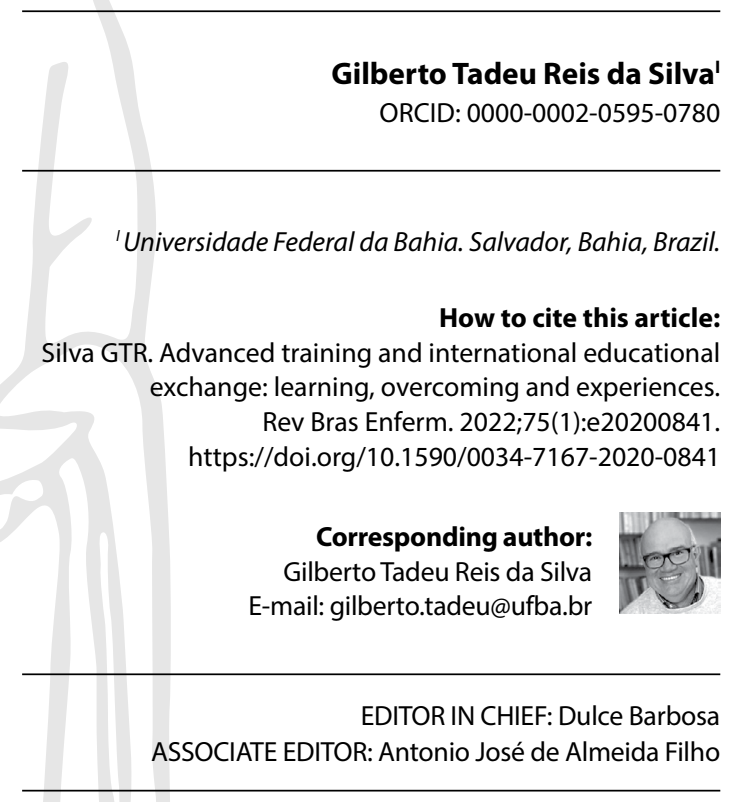

Submission: $07-22-2020$

Approval: 04-18-2021

\begin{abstract}
Objectives: to report my experiences as a researcher during the course of advanced postdoctoral training abroad. Methods: theoretical and methodological option for Max van Manen's phenomenology of practice. The activities were developed in the Health Sciences Research Unit: Nursing, in Portugal, Université Catholique de Louvain, in Belgium, and in Escuela de Enfermeríay Fisioterapia de la Universidad de Castilla-La Mancha, in Spain. Results: participating in a multicenter international research project enabled the acquisition of new scientific knowledge, personal and cultural gains. From a broader perspective, the international graduate and undergraduate nursing networks were strengthened through the mobility of researchers, and overcoming of the "status quo" by the formation of a critical mass environment indispensable for scientific advancement. Final Considerations: sharing the experience that you appropriate is about the power of grasping possibilities of a practical experience, in the context of the world, and going through it, motivated by the desire to make internationalization feasible.

Descriptors: International Educational Exchange; International Cooperation; Internationality; Education Graduate; Phenomenology.
\end{abstract}

\section{RESUMO}

Objetivos: relatar minha vivência de pesquisador durante o percurso de formação avançada de pós-doutoramento no exterior. Métodos: opção teórico-metodológica pela fenomenologia da prática de Max van Manen. As atividades foram desenvolvidas na Unidade de Investigação em Ciências da Saúde: Enfermagem, em Portugal, e na Escuela de Enfermería y Fisioterapia de la Universidad de Castilla-La Mancha, na Espanha. Resultados: participar de um projeto multicêntrico de pesquisa internacional possibilitou aquisição de novos conhecimentos científicos, ganhos pessoais e culturais. Sob uma perspectiva mais ampla, foram fortalecidas as redes internacionais de pós-graduação e licenciatura em Enfermagem, por meio da mobilidade para pesquisadores, e a superação do "status quo", pela formação de ambiente de massa crítica indispensável ao avanço científico. Considerações Finais: compartilhar a vivência que se apropria diz respeito ao poder de captar possibilidades de uma experiência prática, no contexto do mundo e percorrê-la, motivado pelo desejo de tornar factível a internacionalização.

Descritores: Intercâmbio Educacional Internacional; Cooperação Internacional; Internacionalidade; Educação de Pós-Graduação; Fenomenologia.

\section{RESUMEN}

Objetivos: relatar mi experiencia de investigador durante el curso de formación posdoctoral avanzada en el extranjero. Métodos: opción teórico-metodológica por la fenomenología de la práctica de Max van Manen. Las actividades se desarrollaron en la Unidad de Investigación en Ciencias de la Salud: Enfermería, en Portugal, Université Catholique de Louvain, en Bélgica, y en la Escuela de Enfermería y Fisioterapia de la Universidad de Castilla-La Mancha, en España. Resultados: participar de un proyecto de investigación internacional multicéntrico permitió la adquisición de nuevos conocimientos científicos, ganancias personales y culturales. Desde una perspectiva más amplia, se fortalecieron las redes internacionales de posgrado y pregrado en Enfermería, a través de la movilidad para investigadores y la superación del "statu quo", por la formación de un ambiente de masa crítica indispensable para el avance científico. Consideraciones Finales: compartir la experiencia que se apropia tiene que ver con el poder de captar las posibilidades de una experiencia práctica, en el contexto del mundo y aprovecharla, motivado por el deseo de hacer factible la internacionalización. Descriptores: Intercambio Educacional Internacional; Cooperación Internacional; Internacionalidad; Educación de Postgrado; Fenomenología. 


\section{INTRODUCTION}

The public policies that induce the internationalization of Brazilian graduate studies integrate the strategic plans of the universities and the government itself in areas of knowledge that aim to consolidate international networks and improve the quality of studies ${ }^{(1-2)}$.

This report reveals my experience as a researcher in the modality of exchange Post-Doctorate Abroad (PDA), financed by $\mathrm{CNPq}$, in which projects are developed in partnership with foreign research centers of recognized excellence ${ }^{(3-4)}$. On the one hand, the text describes a research approach based on human sciences, with the semiotic use of phenomenological and hermeneutic methods ${ }^{(5-6)}$, and, on the other hand, involves the reader in pedagogical reflection on our experience in a period of advanced research in an international multicenter research.

The manuscript can be seen as a set of methodological suggestions to be employed in research that starts from the experiences of the subjects, as in the human sciences ${ }^{(5)}$. However, in the human sciences as conceived here, research is done assuming a prior interest, and not just for its own sake. From this perspective, I understand it as a fundamental and pedagogical orientation, for researchers postulating a similar trajectory.

So when we raise questions, collect data, describe a phenomenon, and construct textual interpretations, we do so as researchers guided by a phenomenology of practice ${ }^{(5)}$. A research method is just a way of investigating certain kinds of questions. The questions themselves and the way they are understood are the most important starting point, not the method itself.

The institutional release from UFBA occurred through the Faculty Qualification Program (PROQUAD). Gradually, I became aware of the relevance and merit of the proposal, as I would be leading partnerships in multicenter international projects ${ }^{(7)}$ for the university and more specifically for the postgraduate program.

Initially, I went through several steps for project submission, including identification of the proposal, definition of the predominant knowledge area and related areas, elaboration of the activities schedule and submission of the required documents ${ }^{(2)}$. Then, after approval and organization of professional activities, we traveled to Coimbra, Portugal, where we established residence. We chose this city due to the designation with CNPq and the need for travel throughout the study.

Since then, I have had rich experiences that, in the distance, motivate me to share this experience in the project on management models in university hospitals, in order to broaden horizons and reveal less stressful options to those who follow this path. By describing the experience in the first person, I seek to favor access to the intersubjectivity experienced in the relationship with the research subject(s), which, in the distance, favors illuminating a perspective, the meaning of the experience. In this sense, I choose to use a discourse and alignment with the theoretical-methodological referential inspired by Max van Manen's phenomenology of practice ${ }^{(5)}$. To scrutinize the discourse as described in the experience allows me to develop a reflexive analysis of what was said, the pre-reflective. Phenomenology promotes access to the pre-reflective world as we experience it ${ }^{(5)}$. The pre-reflexive is the original experience, that is, the immediate contact with the world before it becomes conscious for the subject.

Phenomenology as a method of inquiry is concerned with the direct and characteristic epistemic (usually perceptual) study with that which presents itself to a cognitive source of information. In this case human experience (phenomenon), as it is lived, and not in the way people think or theorize about what they have experienced. The phenomenology of practice ${ }^{(5)}$ is rooted in pure philosophical phenomenology, but differs from it in that its purpose is not the theoretical-philosophical study, sometimes abstract in nature, but rather the study of everyday personal, professional, cultural, or social practices ${ }^{(3-4,7-8)}$. This movement emerges as a need to "do" phenomenology and not only to think it in an academic way.

In the tone I present, the way certain questions are articulated is related to the research method with which one tends to identify ${ }^{(5)}$. There is, however, a certain dialectic between question and method. Reflection, more than mere whim, is the preferential choice I adopt in this approach to the detriment of others.

This chosen method, first of all, must maintain a certain harmony with the deep interest that makes one an educator who, as he sets out at the beginning, reflects on the journey, and not only on the result at the end.

Becoming an educator requires phenomenological sensibility ${ }^{(6)}$ in relation to lived experience (realities and "life worlds"). In this perspective, pedagogy, in the formation of the educator, requires hermeneutic capacity to obtain the interpretative meaning of the phenomena of the "life world" (Lebenswelt), which allows us to see the pedagogical meaning of situations and relationships in coexistence. And pedagogy also requires dealing with language, so that the research process of textual reflection can contribute to the pedagogical understanding and sensibility of the researcher.

Thus, I will describe the course of advanced training abroad, explaining what I learned, overcame, and experienced, with the intention of provoking reflections about this training.

\section{METHODS}

The activities were scheduled for the period July 2019 to August 2020, under the supervision of a Senior Researcher from the aforementioned institution.

The inter-institutional agreement provides for the entry of researchers as students, which represents an exemption from academic fees and lower mobility and food costs.

The agreement between UFBA and ESEnfC was decisive for choosing this institution. In addition, I considered the institutional profile, the establishment of a previous partnership with the supervisor and the fact that UICISA is the only research unit accredited in the Nursing area by the Science and Technology Foundation in Portugal ${ }^{(3-4,7)}$.

Thus, I understand this free account to be invaluable, not intended as an objective record of what happened, but rather as a vivid reaction to it, written immediately after the event, and as a first word. It is possible to note that this narrative consists of my speaking of the experience in the face of a period just ended. 


\section{RESULTS}

\section{Learning}

The learning was countless and I would like to describe those that I consider most relevant throughout this formative process.

I believe that the beginning of this trajectory was favored by the alignment and previous partnerships with the supervisor abroad, with whom I had already developed projects and publications. Our strategy was to enhance the inter-institutional agreement between UFBA and ESEnfC, which, in recent years, was restricted to the development of collaborative research projects, technical visits, research group meetings and participation in seminars and doctoral panels, mostly remotely ${ }^{(3-4)}$.

From these experiences we were able to do more than we initially proposed, because, besides publishing the results of the research together with the supervisor, the plan of activities indicated the development of actions linked to graduate studies, master's level, showing the relevance of this formative process ${ }^{(4,8)}$. The experiences and exchanges with health services, technical visits and monitoring, dialogue with researchers and investigators, participation in seminars and international scientific events, collaborations in the editorial management of scientific journals and involvement in activities of the original research occurred, allowing an overflow of multilateral cooperation experiences.

There were several demands and the need to plan them in advance, as well as to organize the documents to receive the scholarship and follow up on the legal requirements at the ESEnfC, Université Catholique de Louvain, Universidad de Castilla-La Mancha and at UFBA, demanded time. I would like to point out that the receiving institutions make available an International Relations Office, responsible for the institutional and researcher's documental procedures.

It is also important to highlight the institution's support to foreign students, since some of them chose to keep their research in a remote way during the pandemic, far away from UICISA:E. In addition, the supervisor and the institution followed our routines and the development of the studies every 15 days.

The activities developed during this period were fundamental to strengthen a network of researchers who know each other personally and develop studies in partnership. This allows us to raise production indicators for the institution's research groups.

This experience provided me with learning and enabled me to participate in international research groups, experiencing their movements and different ways of working collectively. It also unveiled possibilities that were unknown to me until then and alternative forms of support in international funding agencies, as well as allowed me to expand partnerships with researchers from different countries, mostly European.

I was able to visit health services and facilities, learn about politics and social development in countries like Belgium, France, Spain, Portugal, and Switzerland, make new friends, learn new languages, and integrate with people from different cultures ${ }^{(7-8)}$. I consider this overflow of cooperation in several areas, of complex interdependencies generating the strengthening of cooperation ties, fundamental to my personal development and growth ${ }^{(4)}$ and multiple learnings that go beyond the academic coexistence and last beyond a research sabbatical.

\section{Overcomings}

Overcoming limitations, difficulties, getting to know new cultures, reinventing ourselves. All of this allows us to mature, to (re)mean habits, to change our "modus" of "being-and-acting-inthe-world," opening possibilities to create a critical mass indispensable to the advancement of scientific research and human knowledge. That's why we grow up in the storms $s^{(4,7-8)}$. However, it is necessary to be prepared, with a reserve of tolerance, detachment, and capacity to deal with the unforeseen events of the investigative process and personal relationships. It is also difficult to deal with the absence of family and friends and differences in culture, food, climate, habits and values.

The feeling of being a "stranger in the nest" is real ${ }^{(4,7)}$, but, with time, it is accompanied by more self-confidence and the ability to relate, which I consider fundamental for the sharing of ideas with researchers of such plural knowledge.

I also consider it essential to value researchers who are prepared for this challenge, who know how to communicate in other languages, who are willing to favor overcoming the "status quo" by learning about other cultures and being open to opportunities to broaden their world view and, concomitantly, to enrich themselves in scientific advancement.

I experienced overcomings $\mathrm{s}^{(3-4)}$, but I prefer to cherish the memories of simplicity and tenacity carefully imprinted on the routes we built. Perhaps one of the most emblematic experiences was sharing the space with students from six countries, with different cultures and ways of working, which required a daily exercise of overcoming limitations, because only then could we maintain cooperation, the sharing of knowledge and personal conviviality.

I also highlight the self-taughtness in the use of data analysis tools, a fact that caused many failures ${ }^{(4)}$, sometimes with hazy perspectives, but that were decoded into important learning.

The support provided by the ESEnfC/UICISA promptly met my needs and facilitated the investigative path immensely. Difficulties are inherent and occurred in the family perspective, in personal and academic relationships, and were aggravated during the pandemic period, when l experienced worries and anxieties, but also the grateful union for a collective good.

\section{Experiences}

Of the various experiences throughout this period, I will describe the most significant, given the need to limit words.

Driven by the goal of consolidating an international collaborative research network ${ }^{(7-8)}$, I experienced the research unit in its "modus operandi". I participated in academic activities and scientific events related to research, as well as in the orientation, revision and correction of articles. I worked for our integration with students from the 1st year of the course, with whom we dialogued about the importance of research and partnership between both universities.

Experiencing the School's daily life ${ }^{(8)}$, its "modus vivendi", included participation in conferences in the master's courses, monitoring of teaching activities, composition of juries for qualification and defense of master's and doctoral degrees.

I highlight the rich opportunity to make technical and academic visits to higher education and health institutions and 
to develop pedagogical activities in post-graduation centers in Belgium, France, Spain and Switzerland, besides Portugal. I have participated in organizing and scientific commissions, workshops, and workshops, both in Brazilian events, in which we involved international partners, and in international symposia, as a full member. The activities also included publications of the research abroad, which represented scientific production from the research developed.

In parallel, during this period I did not refrain from remaining in the "ad hoc" evaluation of manuscripts of Brazilian and international journals.

Postdoctoral advanced training abroad is, for me, an enriching experience in the personal, professional and academic spheres ${ }^{(3,7-8)}$ This experience has revealed the relevance of investigative immersions for researchers and students, through international agreements between research groups or during technical missions of graduate programs, which strengthen the cooperation and trust of mutual dependence.

I reiterate the quality of the partnership established, the intellectual freedom and the unparalleled support of researchers and the supervisor in Coimbra as fundamental aspects to accomplish this research and stimulate the need for massive training to create an environment of critical mass and international mobility.

\section{Study limitations}

It is noteworthy that the type of proposal "experience report" has limitations regarding its reproduction. It is strictly about the experience of the author involved in the advanced training course, his learnings, overcoming and experiences, based on the senses and meanings attributed by the one who experiences it. The scrutiny of the discourse as described in the experience develops for the one who experiences it; in this case, the human experience.

\section{Contributions to the nursing field}

This successful experience report may contribute to explain an advanced training course abroad, its learning, overcoming and experiences, with the intention of raising reflections on the relevance of this formative process. It may also instigate interest regarding this training in the perspective of internationalization and participation in multicenter international research projects with the acquisition of new scientific knowledge, personal and cultural gains. Finally, it may also help in the strengthening of international networks, for the improvement of an investigative training of excellence through this mobility for researchers.

\section{FINAL CONSIDERATIONS}

At the end of this description, I return to the initial question, when I indicate the meanings of this experience as a subject that recovers them, allowing access to what was lived. I consider it to have been something extremely enriching, because it provided significant learning, overcoming, and experiences.

I believe that, at present, we are closer to the goal of strengthening international networks at the graduate and undergraduate levels, in order to improve investigative and academic training for Brazil by promoting mobility and exchange.

To recognize this process is not to decide, but to share the experience that appropriates what is lived. To be able to capture the possibilities of an experience in the context of the world is, without a doubt, a way of providing (pre)presence, so that others get to know this trajectory, its universality of meanings, primarily as something original, and become available to go through it. In this way, we can make the internationalization of teaching and science in Nursing feasible.

\section{FUNDING}

The study received financial support from CNPq through process 205736/2018-1, for the project entitled: MODELS OF HOSPITAL MANAGEMENT IN NURSING: MEMORIES OF NURSES, in the call for Scholarships Abroad / Postdoctoral Fellowships Abroad - PDE, for the period 2019/2020.

\section{AKNOWLEDGEMENTS}

To CNPq, for the Post-Doctoral Scholarship Abroad - PDE and the Federal University of Bahia for the release in the Teacher Qualification Program (PROQUAD).

\section{REFERENCES}

1. Ministério da Educação (BR). Capes. Avaliação da pós-graduação [Internet]. 2019 [cited 2020 Jul 30]. Available from: https://www.gov.br/ capes/pt-br/assuntos/noticias/capes-melhora-ferramentas-de-avaliacao-da-pos-graduacao

2. Peixoto Bezerra V. Post doctoral stage: challenges and possibilities for knowledge consolidation. Rev Enferm UFPI. 2017;6(2):3. https://doi. org/10.26694/reufpi.v6i2.6013

3. Badke MR, Barbieri RL, Martorell-Poveda MA. Internationalization of Brazilian Nursing: doctor sandwich in the Catalonian Region - Spain Texto Contexto Enferm. 2018;27(1):e3620016. https://doi.org/10.1590/0104-07072018003620016

4. Richardson J, Zikic J, The darker side of an international academic career. Career Develop Int. 2007;12 (2):164-86. https://doi. org/10.1108/13620430710733640.

5. Van Manen M. Phenomenology of practice: meaning-giving methods in phenomenological research and writing. California: Left Coast Press, Inc.; 2014. 412 p.

6. Esquivel DN, Silva GTR, Medeiros MO, Soares NRB, Gomes VCO, Costa STL. Produção de estudos em enfermagem sob o referencial da fenomenologia. Rev Baiana Enferm. 2016;30(2):1-10. https://doi.org/10.18471/rbe.v30i2.15004 
7. Kenway J, Fahey J. Policy incitements to mobility: some speculations and provocations. In: Boden R. Dean D, Epstein F, (Eds.). World yearbook of education 2008: geographies of knowledge, geometries of power: higher education in the 21st century. London: Routledge; pp. 161-79.

8. Dalmoni IS, Pereira ER, Silva RM, Gouveia MJ, Sardinheiro JJ. Intercâmbio acadêmico cultural internacional: uma experiência de crescimento pessoal e científico. Rev Bras Enferm. 2013;3(66):442-7. https://doi.org/10.1590/S0034-71672013000300021 